CZASOPISMO INŻYNIERII LACDOWEJ, ŚRODOWISKA I ARCHITEKTURY JOURNAL OF CIVIL ENGINEERING, ENVIRONMENT AND ARCHITECTURE

JCEEA, t. XXXII, z. 62 (1/15), styczeń-marzec 2015, s. 265-278

\author{
Tomasz KAMIZELA ${ }^{1}$ \\ Mariusz KOWALCZYK ${ }^{2}$ \\ Malgorzata WORWĄG
}

\title{
CONDITIONS FOR EFFECTIVE ULTRASONIC DISINTEGRATION OF ACTIVATED SLUDGE SUSPENSION
}

\begin{abstract}
Low-frequency and high energy sonication were used in the experiments on ultrasonic disintegration of activated sludge. Selected operational parameters of sonication were monitored and analyzed. The transformation of solids into a dissolved form by application of ultrasounds was analyzed on the base of changes in the concentrations of carbon, nitrogen and phosphorus. The scope of the research included determination of a five-day biochemical oxygen demand and rate constant of decomposition, which parameters indirectly represented the biodegradability of product of activated sludge disintegration. The study showed that the propagation of ultrasonic wave was highly disintegrating factor, generating a product of the characteristics of concentrated organic solution. By sonication of activated sludge the dissolved phase was enriched particularly in significant amounts of nitrogen and phosphorus. These elements could disturb the processes that require additional source of carbon, thus application of sonication for generation of easily available of organic carbon may seem less feasible. It seems more appropriate application of sonication to reduce the excess sludge through sludge disintegration and biological conversion. For optimum ultrasonic disintegration of activated sludge was considered sonication time $1200 \mathrm{~s}$, which corresponded to the acoustic energy $170 \mathrm{~kJ}$ and specific energy $36 \mathrm{MJ} / \mathrm{kgTS}$. In view of obtained values of the rate constant of decomposition, it was found that the disintegration of sludge required energy sonication in excess of $22 \mathrm{MJ} / \mathrm{kgTS}$. Determination of potential applications of activated sludge subjected to sonication still requires further investigations that would use system for biological wastewater treatment. This would be the most reliable way to prove the suitability of activated sludge sonication in wastewater treatment technologies.
\end{abstract}

Keywords: activated sludge, disintegration, sonication

\footnotetext{
${ }^{1}$ Autor do korespondencji/corresponding author: Tomasz Kamizela, Czestochowa University of Technology, Brzeźnicka 60a, 42-200 Częstochowa, Poland, tel. 34 3257334, tkamizela@is.pcz.czest.pl

${ }^{2}$ Mariusz Kowalczyk, Czestochowa University of Technology

${ }^{3}$ Małgorzata Worwąg, Czestochowa University of Technology
} 


\section{Introduction}

Ultrasonic disintegration is considered to be a promising method for pretreatment of sewage sludge. The disintegration of microbial cells leads to release and solublization of organic substances that can be readily available organic substrates. Sonication was successfully used to facilitate sewage sludge biodegradability and also digestibility. Ultrasonic disintegration resulted in the increase in biogas and methane production and also the reduction of organic matter $[3,7,9$, $10,13]$. Ultrasounds could also be successfully applied to prevent an excess sludge production. In some laboratory-scale experiments activated sludge was sampled from a bioreactor and subjected to sonication, and then returned to a bioreactor for biological oxidation $[6,15]$. Sonication can also support other biological processes in technological wastewater treatment, e.g. metabolic activity of aerobic and anaerobic sludge, and thus can improve the efficiency of biological treatment $[12,14]$. Sonication can also improve the settleability, counteracting the phenomenon of sludge bulking or sludge conditioning method before the dewatering process. However, these applications require careful selection of operating parameters for sonication and usually low energy treatment $[1,5]$.

A number of researchers have investigated the problem of optimizing the input energy for the process of sonication in order to obtain the desired effect of treatment. Feng et al. have identified two significant energy levels of sonication. The first level of sonication was lower than $1000 \mathrm{~kJ} / \mathrm{kg}$ TS. In this case the ultrasound wave propagation does not cause disintegration but only disruption of structure of sludge flocs. The second level was the dose of $E_{S}=5000 \mathrm{~kJ} / \mathrm{kg}$ TS. Above this value disintegration and solubility were intensified. The highest energy examined in this study was $\mathrm{E}_{\mathrm{S}}=26000 \mathrm{~kJ} / \mathrm{kg}$ TS and was defined as the optimal for disintegrating waste activated sludge [4]. Carrere at al. reported that a threshold of specific energy for effective sludge solubilization varied in the range from 1000 to $16.000 \mathrm{~kJ} / \mathrm{kgTS}$ and strongly depened on sludge TS concentration [2]. According to Wang at al. who considered the performance of the disintegration as a function of input energy of ultrasonic wave, the specific energy consumption should be controlled within $50 \mathrm{~kJ} / \mathrm{g}$ TS [11]. Kidak et al. found that sonication at specific energy of $E_{S}=150000 \mathrm{~kJ} / \mathrm{kg}$ TS and higher could effectively disintegrate treated sludge [8].

In the presented work the effect of ultrasonic treatment on activated sludge disintegration was investigated. The objective of this work was to study optimization of sonication in order to improve solubilization of activated sludge. The operational parameters of sonication such as: sonication time, acoustic energy, specific energy and ultrasound power and density were investigated. Also, the potential applications of sonicated sludge were discussed. 


\section{Experimental}

\subsection{Materials}

Activated sludge (AS) were sampled from the activated sludge tank (oxic zone) from the local wastewater treatment plant (WWTP). The average daily flow of sewage treatment plant effluent is $45000.0 \mathrm{~m}^{3} / \mathrm{d}$. The collected sludge was immediately transferred to the laboratory and tested. The total solids (TS) concentration of activated sludge varied between $3.55 \mathrm{~g} / \mathrm{L}$ and $5.69 \mathrm{~g} / \mathrm{L}$ and the volatile solids (VS) were about $70 \%$.

\subsection{Ultrasonic treatment}

Disintegration by ultrasounds was performed with an ultrasonic processor VC750 (Sonics \& Materials Inc., USA) operating at ultrasonic wave frequency of $20 \mathrm{kHz}$. Sludge samples of $1 \mathrm{dm}^{3}$ were subjected to sonication at ambient temperature $\left(20^{\circ} \mathrm{C}\right)$. The sonotrode with a diameter of $19.0 \mathrm{~mm}$ was placed in the centre of the beaker and immersed at about $30.0 \mathrm{~mm}$. The value of the amplitude

propagated ultrasonic wave was set as a percentage of maximum amplitude and kept constant by ultrasonic processor. The maximum amplitude of $\mathrm{A}=61.0 \mu \mathrm{m}(100 \%)$ was tested in this study. Sonication times were following: 240, 480, 720, 960, 1200, 1440 and $1680 \mathrm{~s}$. The energy supplied to the cellular mass unit of activated sludge (specific energy $-\mathrm{E}_{\mathrm{S}}$ ) was calculated from the eq. (1). Ultrasonic power $(\mathrm{P})$ could be calculated after the transformation of the eq. (2). The calculated ultrasonic density $\left(D_{S}\right)$ was also an operational parameter of ultrasonic treatment (eq. (3)).

$$
\begin{aligned}
& \mathrm{E}_{\mathrm{S}}=\frac{\mathrm{E}}{\mathrm{V}_{\mathrm{S}} \cdot \mathrm{TS}^{\prime}}[\mathrm{kJ} / \mathrm{kgTS}] \\
& \mathrm{E}=\mathrm{P} \cdot \mathrm{t}_{\mathrm{S}^{\prime}} \mathrm{J} \\
& \mathrm{D}_{\mathrm{S}}=\frac{\mathrm{P}}{\mathrm{V}_{\mathrm{S}^{\prime}}}[\mathrm{W} / \mathrm{mL}]
\end{aligned}
$$

where: $\mathrm{E}$ - amount of acoustic energy in Joules (watts * seconds) that is being delivered to the probe (energy monitor of ultrasonic processor) $[\mathrm{J}], \mathrm{E}_{\mathrm{S}}-$ specific energy [kJ/kgTS], P - ultrasound power [W], $\mathrm{t}_{\mathrm{S}}$ - sonication time [s], TS - total solids concentration in treated AS samples $\left[\mathrm{g} / \mathrm{dm}^{3}\right], \mathrm{V}_{\mathrm{S}}-$ sample volume $\left[\mathrm{dm}^{3}\right]$.

The parameters of $t_{S}, E, P, E_{S}, D_{S}$ have been identified as the independent variables and defined as operational parameters of the process of sonication. 


\subsection{Parameter analysis}

The effects of sonication were monitored based on the concentrations of carbon, nitrogen and phosphorus compounds. The measurement of total carbon (TC), total organic carbon (TOC), total nitrogen (TN) and total phosphorus (TP) were taken on soluble fractions of sludge. The soluble fraction was defined as the fraction obtained after centrifugation and filtration. Samples were centrifuged at $10000,0 \mathrm{rcf}$ for $15.0 \mathrm{~min}$. The supernatant was filtrated through a cellulose nitrate membrane $(0.45 \mu \mathrm{m}$ pore size $)$. Total carbon, total organic carbon and

total nitrogen in dissolved forms were measured by multi N/C analyzer (Analytik Jena UK). Concentration of soluble total phosphorus (TP) was measured by a spectrophotometer HACH DR 5000. The measurement of total phosphorus in the solid form was performed by spectrophotometry after mineralization. Biochemical oxygen demand of sonicated activated sludge measured tested without sample pretreatment. Determination of the biochemical oxygen demand carried out with the manometric method using a set of WTW OXI TOP with continuous measurement of the momentary value of BOD. Maintaining the right conditions of BOD measurements makes the reaction as the first order, hence the resulting variable was also the value of the five-day biochemical oxygen demand $\left(\mathrm{BOD}_{5}\right)$ and rate constant of decomposition (k). Total solids (TS) and volatile solids (VS) were determined according to the Polish Standards.

\subsection{Statistical analysis}

The obtained results were presented graphically in the form of central tendency which was arithmetic means (AVG). The statistical dispersion of data around the arithmetic mean was characterized by the standard deviation (STDV). In order to determine the nature of the relationship between a dependent variable (concentrations of TC, TOC, TN, TP) and independent variables ( $t_{\mathrm{s}}, \mathrm{E}, \mathrm{P}, \mathrm{E}_{\mathrm{s}}, \mathrm{D}_{\mathrm{S}}$ ) simple and multiple regression was used. Simple linear regression (least squares regression line) best represented observations in a bivariate data set. The equation for simple linear regression was:

$$
\mathrm{Y}=\mathrm{b}_{0}+\mathrm{b}_{1} \cdot \mathrm{X}_{1}
$$

where: $\mathrm{b}_{0}-\mathrm{a}$ intercept, $\mathrm{b}_{1}-$ the regression coefficient, $\mathrm{X}-$ the independent variable, $\mathrm{Y}$ - the value of the dependent variable.

The coefficient of determination $\left(\mathrm{R}^{2}(\mathrm{SL})\right)$ was calculated for all equations of simple linear regressions. In the equation of multiple linear regression there were at least two of all the independent variables (eq. (5)).

$$
\mathrm{Y}=\mathrm{b}_{0}+\mathrm{b}_{1} \cdot \mathrm{X}_{1}+\mathrm{b}_{2} \cdot \mathrm{X}_{2}+\ldots+\mathrm{b}_{\mathrm{P}} \cdot \mathrm{X}_{\mathrm{P}}
$$


Multiple regression analysis was performed as stepwise multiple regression with forward selection procedure. This procedure evaluates the independent variables at each step by inserting or removing them from the regression equation and terminates when the coefficient of determination of linear regression $\left(\mathrm{R}^{2}(\mathrm{ML})\right)$ is maximized. Stepwise multiple regression allowed to choose the most statistically significant independent variables as the best predictors of the effects of sonication of activated sludge. The multiple regression tested the hypothesis that the independent variable $\left(X_{1}-X_{P}\right)$ does not affect the value of the dependent variable $Y$. If the calculated value of test probability (p-value) is less than the accepted significance level alpha $(\alpha=0.05)$ then the null hypothesis was rejected. In other words, the tested variable $\left(X_{1}-X_{P}\right)$ had a statistically significant impact on the value of $\mathrm{Y}$. Analysis of data and regression analysis were using with STATISTICA 7.1 (StatSoft Inc., Poland).

\section{Results}

Time of ultrasonic wave propagation was the primary operational variable of the process of sonication. Extending the sonication time resulted in increased acoustic energy delivered to the sample. Depending on the amount of acoustic energy and the total solid concentration of AS the specific energy $\left(E_{S}\right)$ varied. Average values of the acoustic energy and specific energy are presented in table 1. Independently of the applied sonication time, acoustic power was calculated with the eq. (2). Acoustic power in the range of applied sonication time remained stable and amounted to $\mathrm{P}=140.9 \pm 3.92 \mathrm{~W}$. Due to the fact that $1 \mathrm{dm}^{3}$ of sludge sample was subjected to sonication, ultrasonic density was calculated with the eq. (3) and amounted to DS $\approx 0.141 \mathrm{~W} / \mathrm{cm}^{3}$.

Table 1. Sonication times and the corresponding values of input ultrasonic energy

Tabela 1. Zastosowane czasy i wielkości energetyczne sonifikacji

\begin{tabular}{|l|c|c|c|c|c|c|c|}
\hline Sonication time [s] & 240 & 480 & 720 & 960 & 1200 & 1440 & 1680 \\
\hline Acoustic energy [kJ] & 32.26 & 67.46 & 102.65 & 137.84 & 170.04 & 198.26 & 230.08 \\
\hline Specific energy [kJ/kgTS] & 7199 & 14852 & 22005 & 29759 & 36612 & 43356 & 52258 \\
\hline
\end{tabular}

With reference to the value of a specific energy cited in the introduction, the applied maximum sonication time $\mathrm{t}_{\mathrm{s}}=1680 \mathrm{~s}$ should generate optimal conditions for disintegration. Also, it was pointed out that the optimal value of the specific energy can be higher as well as lower than this referred value. At lower sonication time (specific energy), undoubtedly disintegration of activated sludge microorganisms occurred. Due to the system capacity for sludge disintegration the 28 minutes sonication (at sufficient ultrasonic power and specific energy) seemed to be definitely too long. Therefore, in the presented investigations the 
main focus was placed on determining the intensity of disintegration at lower sonication time and the optimization of process parameters.

Cyclical increase in time of sludge sonication resulted in rapid growth of the total carbon (TC) concentration in the dissolved phase of disintegrated sludge (fig. 1). This was characteristic for sonication time not exceeding the 1200 s. Above this value the rate of solubilization of carbon decreased. Generally, the release of carbon to the dissolved phase was a linear function. This was confirmed by the determination coefficient for the regression rate of $\mathrm{R}^{2}=0.94$. The carbon concentrations produced during sonication were up to $700 \mathrm{mg} / \mathrm{dm}^{3}$. This resulted in saturation of the solution with organic substance that is a biodegradable and readily available substrate. This was confirmed by the concentration of total organic carbon (TOC) that reached a maximum value of approximately $650 \mathrm{mg} / \mathrm{dm}^{3}$. The TOC concentrations will determine the quality of a product obtained from sonication of sludge that is used as a substrate by microorganisms (fig. 2.).

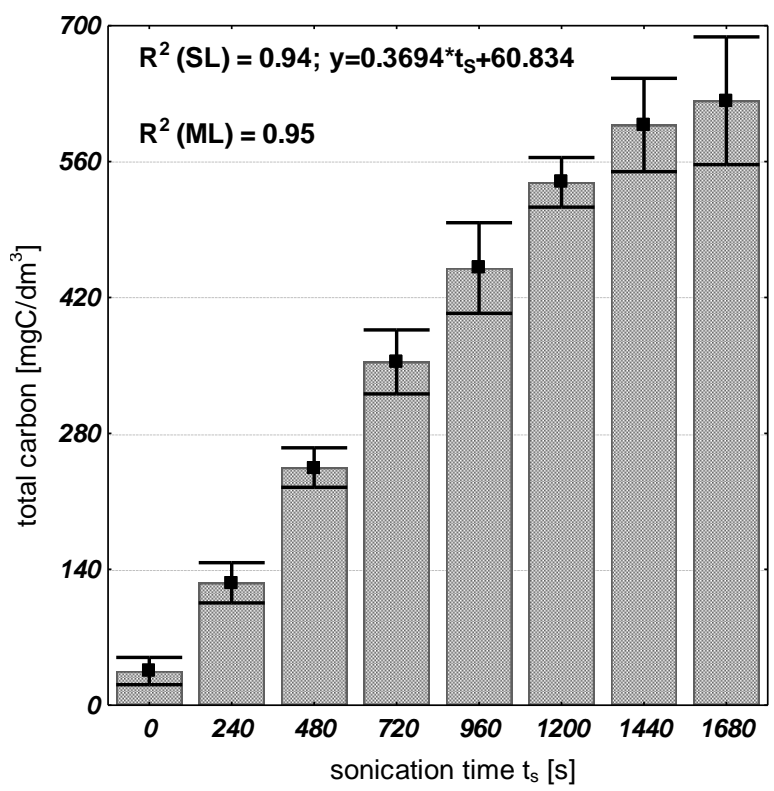

Fig. 1. Effect of sonication time on the total carbon (TC) concentrations in liquid phase of disintegrated sludge

Rys. 1. Zmiany stężenia węgla ogólnego w cieczach osadowych zdezintegrowanej zawiesiny osadu czynnego

Nitrogen is also the fundamental component of microbial cell mass. Thus, 28 minute sonication resulted in the maximum concentration of nitrogen in the dissolved phase, which was $207 \mathrm{mg} / \mathrm{dm}^{3}$ (fig. 3). The release rate of nitrogen 
was three times lower, than in the case of TC and TOC solubilization $\left(b_{1}=0.1144\right)$. It was also observed that with increasing sonication time the increase in the concentration of nitrogen was significantly smaller. This resulted in accuracy of the linear regression and the regression equation was reliable in $\left.81 \%\left(\mathrm{R}^{2}(\mathrm{SL})=0.81\right)\right)$.

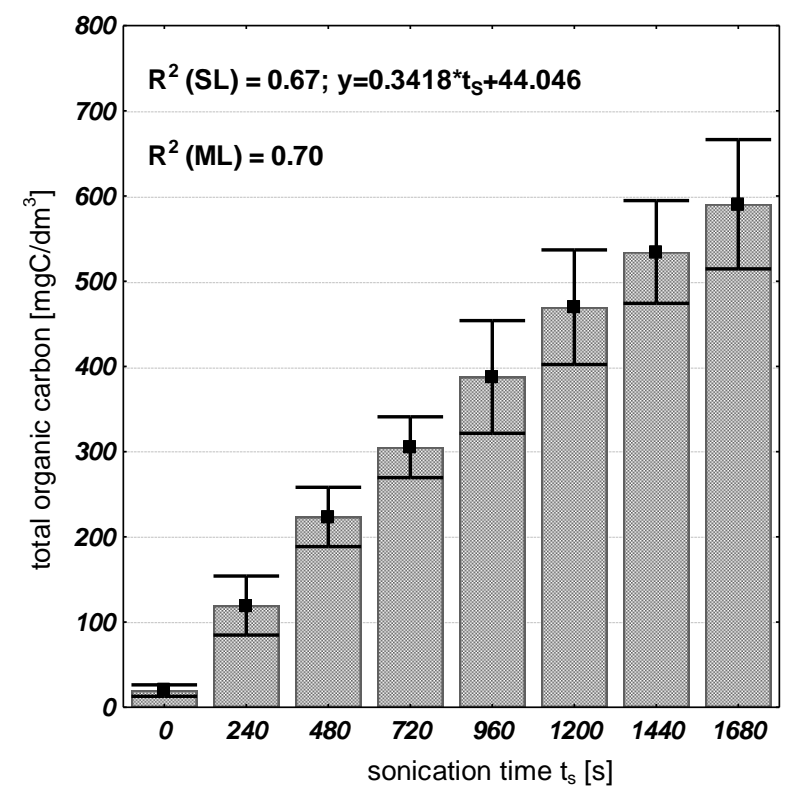

Fig. 2. Effect of sonication time on the total organic carbon (TOC) concentrations in liquid phase of disintegrated sludge

Rys. 2. Zmiany stężenia ogólnego węgla organicznego w cieczach osadowych zdezintegrowanej zawiesiny osadu czynnego

After sonication time of $1680 \mathrm{~s}$ the maximum concentration of total phosphorus amounted to $50 \mathrm{mg} / \mathrm{dm}^{3}$ was achieved (fig. 4). It was a significantly high value, especially as the inflow to the wastewater treatment plant contained much lower concentrations of phosphorus. It can be assumed that the release of compounds containing phosphorus in function of sonication time may be rather a polynomial function. The concentration of total phosphorus estimated from the equation of linear regression at about $30 \%$ will be incorrect.

Generally, the product obtained from AS sonication showed higher concentrations of carbon nitrogen and phosphorus than raw wastewater flowing into wastewater treatment plants. Thus, depending on the amount of treated sludge the additional load of contaminants will be produced. This is an important issue 


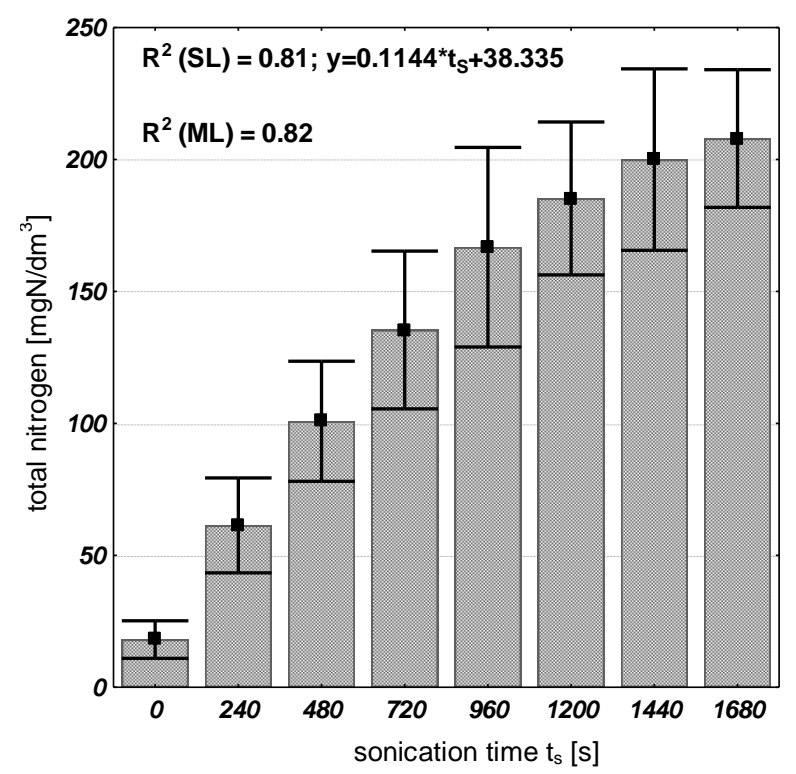

Fig. 3. Nitrogen (TN) release profiles to the liquid phase as a result of the AS sonication

Rys. 3. Zmiany stężenia azotu ogólnego w cieczach osadowych zdezintegrowanej zawiesiny osadu czynnego

because it links ultrasonic disintegration with the operation and efficiency of a bioreactor. Biological treatment technology required to comply with the relevant load of substrate in order to achieve a high degree of contaminant removal. As a result of sonication the dissolved phase was saturated with nitrogen and phosphorus was confirmed by the concentration ratio of carbon to nitrogen and phosphorus (TC/TN and TC/TP). The ratios of TC/TN did not exceed the value of 3, and the TC/TP of 15 (table 2). Considering the type of biological processes such as denitrification and dephosphatation, they cannot occur efficiently at such low ratios.

It was observed that increasing sonication time, and thus the specific energy, causes the increase in the calculated ratios. Thus, the use of high specific energy of $50000 \mathrm{~kJ} / \mathrm{kg}$ TS may not be justified. Therefore, sonication of sludge may be considered as a method for enrichment of a solution (dissolved phase) in nitrogen and phosphorus compounds. It is possible that sonication of activated sludge would be a suitable option for application in industrial wastewater treatment plants where deficiencies of these elements are often observed. In the case of municipal WWTPs - which usually have the problem with the effective reduction of nitrogen and phosphorus - the use of sonication appears to be limited. 


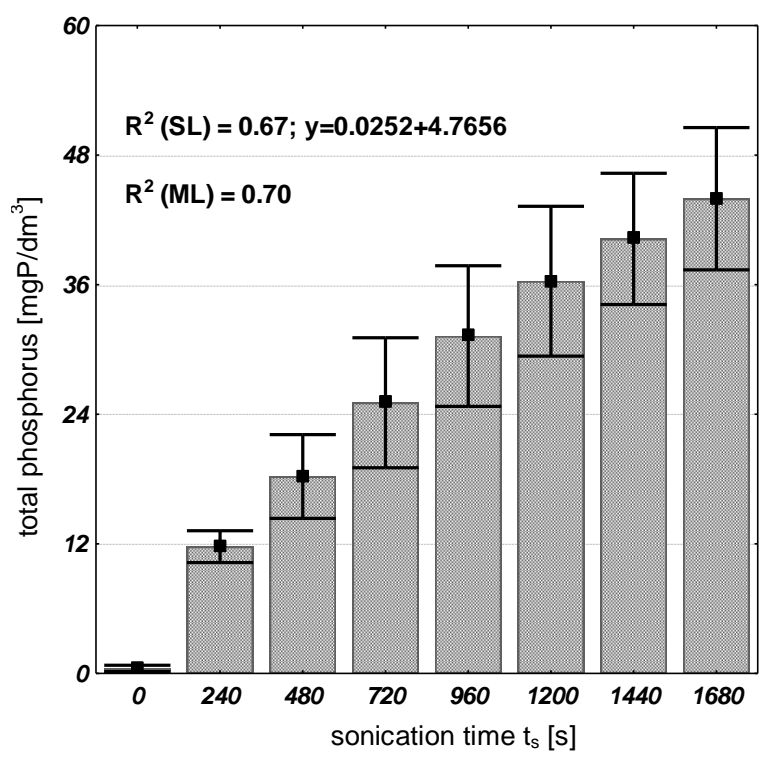

Fig. 4. Phosphorus (TP) release profiles to the liquid phase as a result of the AS sonication

Rys. 4. Zmiany stężenia fosforu ogólnego w cieczach osadowych zdezintegrowanej zawiesiny osadu czynnego

Tabela 2. The mean values of calculated ratios of carbon, nitrogen and phosphorus concentrations Table 2. Średnie wartości ilorazu stężeń węgla i azotu oraz fosforu ogólnego w cieczy osadowej w funkcji czasu sonifikacji

\begin{tabular}{|l|c|c|c|c|c|c|c|}
\hline Sonication time [s] & 240 & 480 & 720 & 960 & 1200 & 1440 & 1680 \\
\hline TC/TN & 2.06 & 2.45 & 2.62 & 2.71 & 2.91 & 3.00 & 3.00 \\
\hline TC/TP & 11.45 & 13.61 & 14.16 & 14.52 & 14.97 & 14.95 & 14.48 \\
\hline
\end{tabular}

The impact of ultrasonic wave propagation was characterized by the value of the five-day biochemical oxygen demand of sonicated AS (fig. 5) and respectively the value of the rate constant of decomposition (fig. 6). $\mathrm{BOD}_{5}$ of non - sonicated AS was $1037 \mathrm{mgO}_{2} / \mathrm{dm}^{3}$. As a result of sonication rather slow increase of $\mathrm{BOD}_{5}$ values was observed from $1047 \mathrm{mgO}_{2} / \mathrm{dm}^{3}\left(\mathrm{t}_{\mathrm{s}}=240 \mathrm{~s}\right)$ to $1153 \mathrm{mgO}_{2} / \mathrm{dm}^{3}\left(\mathrm{t}_{\mathrm{s}}=1680 \mathrm{~s}\right)$ despite the use of high specific energy approximately $53 \mathrm{MJ} / \mathrm{kg}$ TS. The opposite tendency was characteristic of a rate constant (k). A kind of a critical value was sonication time $t_{\mathrm{S}}=720 \mathrm{~s}(22 \mathrm{MJ} / \mathrm{kg}$ TS $)$. For this sonication time obtained value of $\mathrm{k}=0.34 \mathrm{~d}^{-1}$, which was evident lower than for the non sonicated AS $\left(\mathrm{k}=0.39 \mathrm{~d}^{-1}\right)$. 


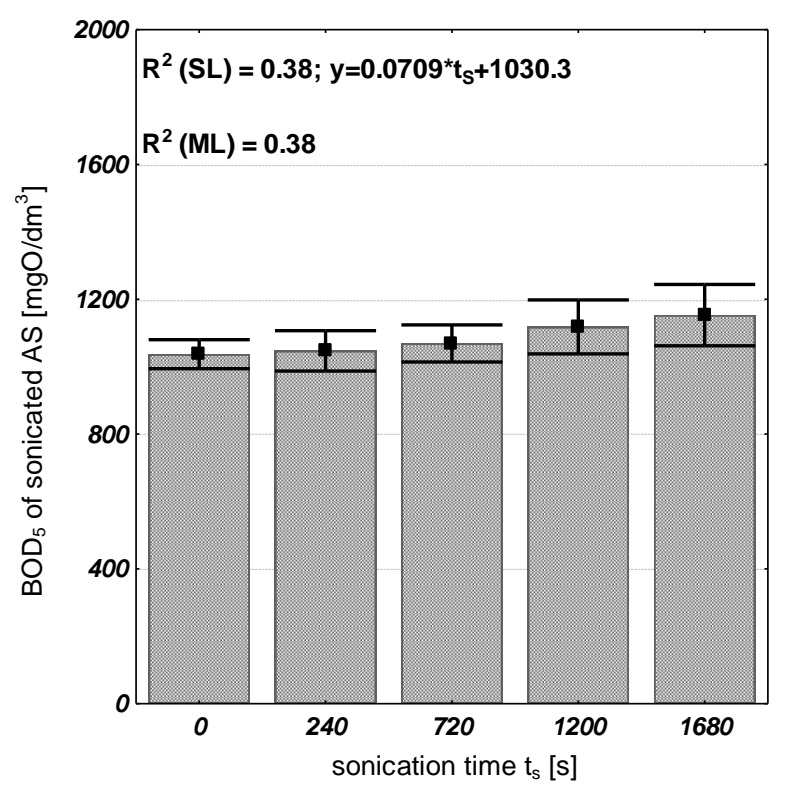

Fig. 5. $\mathrm{BOD}_{5}$ of sonicated activated sludge

Rys. 5. BZT $_{5}$ zdezintegrowanej zawiesiny osadu czynnego

Regression analysis performed by stepwise method allowed to choose the most authoritative independent variables (operating parameters of sonication). Table 3 shows the equations of multiple regression and the most statistically significant independent variables in detail.

For the identified TOC, TC, TN and TP concentrations acoustic energy supplied to the sludge sample and also ultrasonic density (individual case) were the most suitable arguments of linear function. They were operating parameters that best correlated with changes of determined indicators. Other variables as sonication time, specific energy, total solids and ultrasonic power were excluded from the multiple regression equation. The intercept describing the initial characteristics of waste activated sludge, and thus susceptibility of sludge to disintegration was also statistically significant. Equations of multiple linear regression for concentrations of $\mathrm{BOD}_{5}$ and $\mathrm{k}$ have a more complex form. In these cases, the total solids concentration in treated AS samples, sonication time, acoustic and specific energy were a best predictors of the effects of sonication. This proved that the modeling of biochemical processes is much more complicated and may be subject to larger errors. 


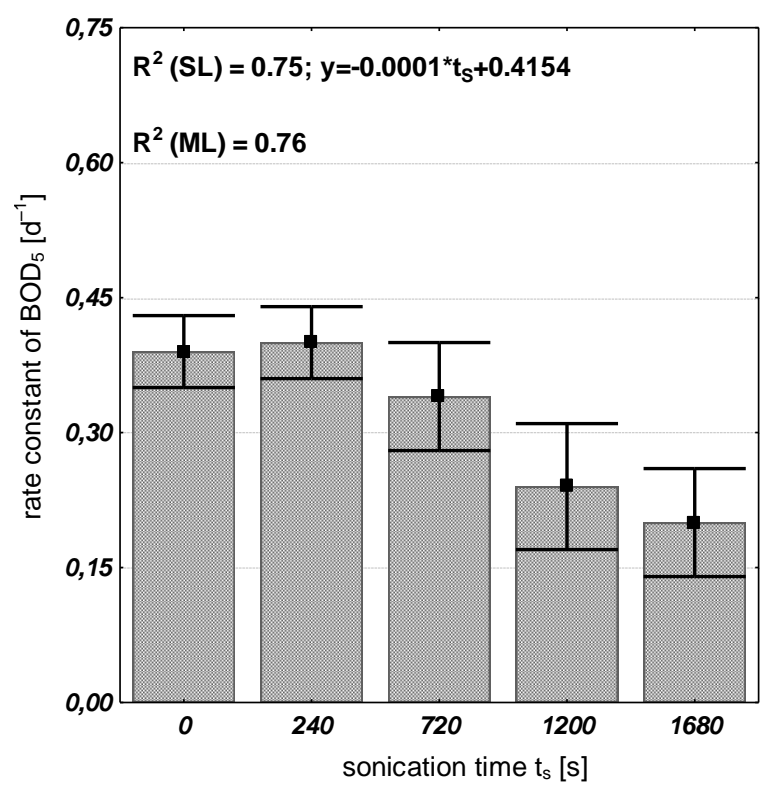

Fig. 6. Changes in rate constant of $\mathrm{BOD}_{5}$ as a function of sonication time

Rys. 6. Zmiany wartości stałej szybkości rozkładu w funkcji czasu sonifikacji

Table 3. Results of multiple regression analysis

Tabela 3. Wyniki analizy regresyjnej prowadzonej metodą regresji krokowej

\begin{tabular}{|c|c|c|c|c|c|c|c|}
\hline $\begin{array}{l}\text { Para- } \\
\text { meter }\end{array}$ & $\begin{array}{c}y \text {-inter- } \\
\text { cept }\end{array}$ & $\begin{array}{c}\mathbf{t}_{\mathbf{S}} \\
{[\mathbf{s}]}\end{array}$ & $\begin{array}{c}\mathbf{E} \\
{[\mathbf{J}]}\end{array}$ & $\begin{array}{c}\text { TS } \\
{[\mathrm{g} / \mathrm{L}]}\end{array}$ & $\begin{array}{c}E_{S} \\
{[\mathrm{~kJ} / \mathrm{kg} \mathrm{TS}]}\end{array}$ & $\underset{[\mathbf{W}]}{\mathbf{P}}$ & $\underset{[W / m L]}{D_{S}}$ \\
\hline \multirow{2}{*}{$\begin{array}{c}\mathrm{TC} \\
{\left[\mathrm{mg} / \mathrm{dm}^{3}\right]}\end{array}$} & \multicolumn{7}{|c|}{$\mathrm{TC}=59.79+0.00262 \mathrm{E}$} \\
\hline & $>0.0001$ & - & $>>0.0001$ & - & - & - & - \\
\hline \multirow{2}{*}{$\begin{array}{c}\text { TOC } \\
{\left[\mathrm{mg} / \mathrm{dm}^{3}\right]}\end{array}$} & \multicolumn{7}{|c|}{$\mathrm{TOC}=43.55+0.00242 \mathrm{E}$} \\
\hline & $>>0.0001$ & - & $>>0.0001$ & - & - & - & - \\
\hline \multirow{2}{*}{$\begin{array}{c}\mathrm{TN} \\
{\left[\mathrm{mg} / \mathrm{dm}^{3}\right]}\end{array}$} & \multicolumn{7}{|c|}{$\mathrm{TN}=37.95+0.00081 \mathrm{E}$} \\
\hline & $>>0.0001$ & - & $>0.0001$ & - & - & - & - \\
\hline \multirow{2}{*}{$\begin{array}{c}\mathrm{TP} \\
{\left[\mathrm{mg} / \mathrm{dm}^{3}\right]}\end{array}$} & \multicolumn{7}{|c|}{$\mathrm{TP}=4.72+0.00524 \mathrm{D}_{\mathrm{S}}$} \\
\hline & $>>0.0001$ & - & - & - & - & - & $>0.0001$ \\
\hline \multirow{2}{*}{$\begin{array}{c}\mathrm{BOD}_{5} \\
{\left[\mathrm{mg} / \mathrm{dm}^{3}\right]}\end{array}$} & \multicolumn{7}{|c|}{$\mathrm{BOD}_{5}=869.2213+0.2040 \mathrm{t}_{\mathrm{S}}+37.6145 \mathrm{TS}-0.0039 \mathrm{E}$} \\
\hline & $>0.0001$ & 0.0003 & 0.005 & 0.0005 & - & - & - \\
\hline $\mathrm{k}$ & \multicolumn{7}{|c|}{$\mathrm{k}=0.236423+0.001463 \mathrm{tS}-0.000011 \mathrm{E}+0.034409 \mathrm{TS}$} \\
\hline$\left[\mathrm{d}^{-1}\right]$ & $>0.0001$ & 0.05 & 0.004 & 0.001 & 0.04 & - & - \\
\hline
\end{tabular}




\section{Conclusions}

Effects of solubilization of activated sludge organic matter exposed to ultrasonic disintegration were observed during the experiments. This is of significant importance due to substrate availability to microorganisms. By sonication of AS the dissolved phase was enriched particularly in significant amounts of nitrogen and phosphorus. These elements could disturb the processes that require additional source of carbon, thus application of sonication for generation of easily available source of organic carbon may seem less feasible. It seems more appropriate application of sonication to reduce the excess sludge through sludge disintegration and biological conversion.

Taking into account the values $\mathrm{BOD}_{5}$ and $\mathrm{k}$ it should be noted that they were dependent on a number of phenomena which occur simultaneously. As a result of low energy sonication there was the breakdown of structure of activated sludge flocs and thus to the surrounding solution both microorganisms and extracellular polymeric substances was released. Increasing sonication energy lead to decomposition and solubilization of organic substances, reduction the number of viable micro-organisms as well as other changes in the metabolic activity of microorganisms. Especially on the basis of the rate constant, obtained for the sonication time $t_{S}=720 \mathrm{~s}\left(E_{S}=22005 \mathrm{~kJ} / \mathrm{kg}\right.$ TS $)$ specified two impact areas of sonication. This sonication time was considered as the technological line between sonification supporting auto-mineralization (aerobic digestion) and ultrasonic sludge disintegration

Transformations resulted from sonication generally showed linear relationships. However, sonication time above $1200 \mathrm{~s}\left(\mathrm{E}>170 \mathrm{~kJ}\right.$ and $\mathrm{E}_{\mathrm{S}}>36000 \mathrm{~kJ} / \mathrm{kg}$ TS) is a potential area where the rate of releasing solid substances into dissolved phase was slowing down. Therefore, the increase in energy inputs may be unreasonable and uneconomical thus sonication time $t_{S}=1200 \mathrm{~s}$ should be considered the most advantageous time of ultrasonic disintegration of activated sludge.

Generally, determination of potential applications of activated sludge subjected to sonication requires further investigations that would use system for biological wastewater treatment. This would be the most reliable method to determine the relevance and importance of the process of sonication.

\section{Acknowledgements}

This work was supported by the grant No. BS/PB-401-301/11 (Faculty of Environmental Engineering and Biotechnology, Czestochowa University of Technology).

\section{References}

[1] Bień J., Kamizela T., Kowalczyk M., Mrowiec M.: Possibilities of gravitational and mechanical separation of sonicated activated sludge suspension. Environmental Protection Engineering, 2009, no. 35(2), pp. 67-72. 
[2] Carrere H., Dumas C., Battimelli A., Batstone D.J., Delgenes J.P., Steyer J.P., Ferrer I.: Pretreatment methods to improve sludge anaerobic degradability: A review. Journal of Hazardous Materials, no. 183, 2010, pp. 1-15.

[3] Cao X.Q., Chen J., Cao Y.L., Zhu J.Y., Hao X.D.: Experimental study on sludge reduction by ultrasound. Water Science and Technology, no. 54(9), 2006, pp. 8793.

[4] Feng X., Lei H., Deng J., Yu Q., Li H.: Physical and chemical characteristics of waste activated sludge treated ultrasonically. Chemical Engineering and Processing, no. 48, 2009, pp. 187-194.

[5] Gogate P.R., Kabadi A.M.: A review of applications of cavitation in biochemical engineering/biotechnology. Biochemical Engineering Journal, no. 44, 2009, pp. 6072.

[6] He J., Wan T., Zhang G., Yang J.: Ultrasonic reduction of excess sludge from activated sludge system: Energy efficiency improvement via operation optimization. Ultrasonics Sonochemistry, no. 18, 2011, pp. 99-103.

[7] Hogan F., Mormede S., Clark P., Crane M.: Ultrasonic sludge treatment for enhanced anaerobic digestion. Water Science \& Technology, no. 50(9), 2004, pp. 2532.

[8] Kidak R., Wilhelm A.M., Delmas H.: Effect of process parameters on the energy requirement in ultrasonical treatment of waste sludge. Chemical Engineering and Processing, no. 48, 2009, pp. 1346-1352.

[9] Pérez-Elvira S., Fdz-Polanco M., Plaza F.I., Garralón G., Fdz-Polanco F.: Ultrasound pre-treatment for anaerobic digestion improvement. Water Science \& Technology, no. 60(6), 2009, pp. 1525-1532.

[10] Salsabil M.R., Prorot A., Casellas M., Dagot C.: Pre-treatment of activated sludge: Effect of sonication on aerobic and anaerobic digestibility. Chemical Engineering Journal, no. 148, 2009, pp. 327-335.

[11] Wang F., Lu S., Ji M.: Components of released liquid from ultrasonic waste activated sludge disintegration. Ultrasonics Sonochemistry, no. 13, 2006, pp. 334-338.

[12] Xie B., Liu H., Yan Y.: Improvement of the activity of anaerobic sludge by lowintensity ultrasound. Journal of Environmental Management, 2009, no. 90, 260264.

[13] Zawieja I., Wolny L., Wolski P.: Influence of excessive sludge conditioning on the efficiency of anaerobic stabilization process and biogas generation. Desalination, no. 222, 2008, pp. 374-381.

[14] Zhang G., Zhang P., Gao J., Chen Y.: Using acoustic cavitation to improve the bioactivity of activated sludge. Bioresource Technology, no. 99, 2008, pp. 1497-1502.

[15] Zhang G., Zhang P., Yang J., Chen Y.: Ultrasonic reduction of excess sludge from the activated sludge system. Journal of Hazardous Materials, no. 145, 2007, pp. 515-519.

\section{WARUNKI SKUTECZNEJ DEZINTEGRACJI ULTRADŹWIĘKOWEJ ZAWIESINY OSADU CZYNNEGO}

Streszczenie 
Celem przeprowadzonych badań była optymalizacja procesu dezintegracji ultradźwiękowej zawiesiny osadu czynnego. Postępowanie optymalizacyjne opierało się na zastosowaniu propagacji fali ultradźwiękowej o stałej częstotliwości i amplitudzie oraz zmiennych czasów sonifikacji. Zakres badań obejmował oznaczenie stężeń węgla, azotu i fosforu uwolnionych do fazy ciekłej w wyniku oddziaływania dezintegracyjnego fali ultradźwiękowej. Na podstawie pomiarów biochemicznego zapotrzebowania na tlen określono również stałą szybkości rozkładu, co pośrednio stanowiło o podatności na biodegradację otrzymanego produktu dezintegracji. Przeprowadzone badania wykazały, że fala ultradźwiękowa jest wysoce dezintegrującym czynnikiem, generującym produkt o charakterystyce stężonego roztworu organicznego. Sonifikacja zawiesiny osadu czynnego szczególnie doprowadziła do wzbogacenia fazy rozpuszczonej w znaczne ilości azotu i fosforu. Ze względu na stężenia biogenów zastosowanie dezintegracji ultradźwiękowej zawiesin osadu czynnego w dominującym celu generacji łatwo dostępnego węgla organicznego uznano za ograniczone. Właściwsze wydaje się zastosowanie sonifikacji w celu zmniejszenia ilości osadu nadmiernego poprzez jego dezintegrację i recyrkulację do komory osadu czynnego. Za optymalne parametry dezintegracji ultradźwiękowej zawiesiny osadu czynnego uznano sonifikację w czasie $1200 \mathrm{~s}$, co odpowiadało wprowadzonej energii akustycznej $170 \mathrm{~kJ}$ oraz właściwej energii sonifikacji $\mathrm{ES} \approx 36 \mathrm{MJ} / \mathrm{kg}$ s.m. Z uwagi na uzyskane wartości stałej szybkości rozkładu stwierdzono, że dezintegracja osadu czynnego wymaga energii sonifikacji przekraczającej wartość $22 \mathrm{MJ} / \mathrm{kg}$ s.m. Określenie potencjalnych zastosowań dezintegracji zawiesiny osadu czynnego wymaga jeszcze dalszych badań z wykorzystaniem systemu biologicznego oczyszczania ścieków. Będzie to najbardziej wiarygodny sposób określenia możliwości i przydatność sonifikacji w technologii oczyszczania ścieków.

Słowa kluczowe: osad czynny, dezintegracja, sonifikacja

Przestano do redakcji: $2.10 .2014 r$.

Przyjęto do druku: 28.03.2015 r.

DOI: $10.7862 / \mathrm{rb} .2015 .18$ 